\title{
SINGLE-WALLED CARBON NANOTUBES EXHIBIT CIRCULAR DICHROISM WHEN WRAPPED WITH DNA
}

Gordana Dukovic, Milan Balaz, Peter Doak, Nina D. Berova, Ming Zheng, Robert S.
Mclean, Louis E. Brus

\section{SUPPORTING INFORMATION}

Samples. Single-walled carbon nanotubes (SWNTs) produced by the CoMoCAT method $^{1}$ were solubilized using $\mathrm{d}(\mathrm{GT})_{20}$ as described elsewhere. ${ }^{2}$ Samples with one predominant nanotube species, $(6,5)$, were obtained using anion exchange chromatography. ${ }^{3}$ Buffer exchange of DNA-SWNT solutions was carried out using Microcon ${ }^{\circledR}$ centrifugal filter YM-100 (Millipore, Bedford, MA). All samples used in spectroscopy were in $\mathrm{D}_{2} \mathrm{O}$, at concentrations of $\sim 5 \mu \mathrm{g} / \mathrm{mL}$. The mass ratio of DNA and SWNTs is estimated to be $\sim 1 .^{4}$

Spectroscopy. UV-vis-NIR spectra were recorded using a Lambda 19 spectrometer (Perkin Elmer). Circular dichroism (CD) spectrum in Figure 1 of the Communication was measured on a JASCO J-820 spectrophotometer equipped with EXWL-attachment for near IR measurements (1100-750nm). All other CD spectra were recorded on a JASCO J810 spectrophotometer equipped with a circulating cooling/heating bath. The optical path length in all measurements was $1 \mathrm{~cm}$.

Absorption and CD spectra of DNA-SWNT and d(GT) 20 are shown in Figures $\mathrm{S} 1 \mathrm{a}$ and b below.
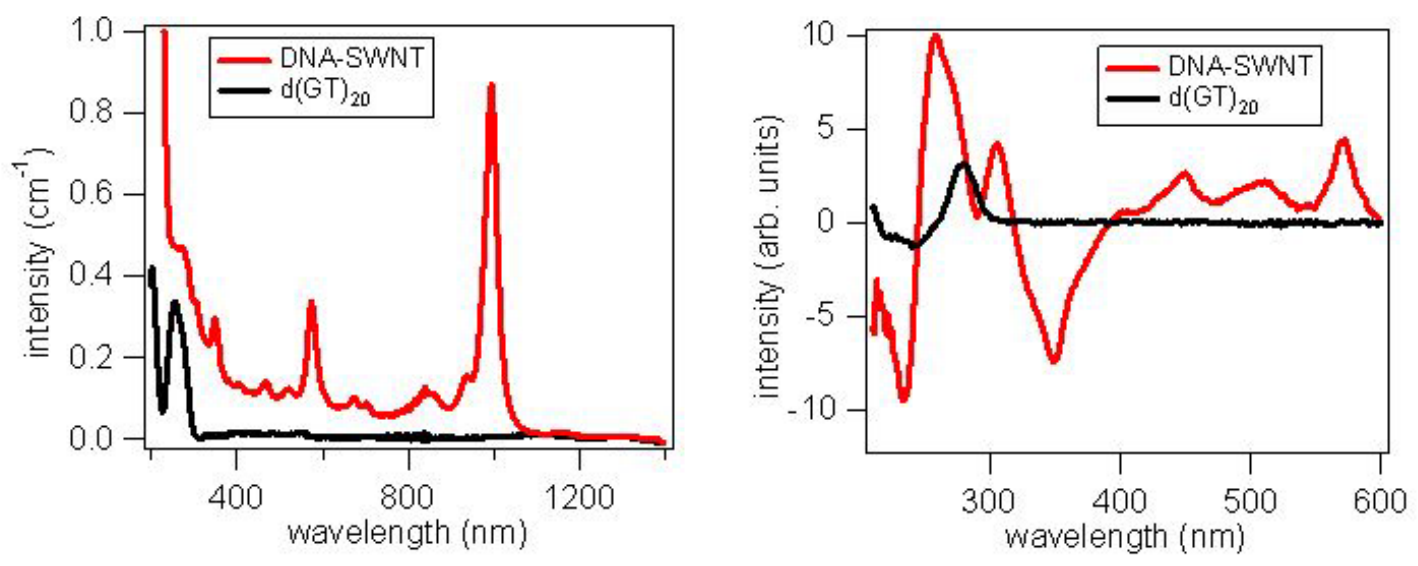

Figure S1. (a) Absorption and (b) CD spectra of DNA-SWNT and d(GT) $)_{20}$.

Exchange of DNA with NaDDBS. Due to the strength of the interaction between nanotube sidewall and DNA, it is difficult to remove the $d(G T)_{20}$ from the nanotube sidewall. To accomplish this, a large excess of sodium dodecyl benzenesulfonate 
NaDDBS, a very good nanotube surfactant, was used to replace the DNA. To carry out the experiment, the original elution buffer was replaced with $1 \% \mathrm{NaDDBS}$ in D2O using YM-100 filters. The solution was incubated a room temperature for $24 \mathrm{hrs}$ and monitored by the blue-shift of the absorption peak (994 nm $\rightarrow 980 \mathrm{~nm}$ ) corresponding to the nanotube $E_{11}$ transition, the exact energy of which is very sensitive to the nanotube environment. The estimated degree of replacement is at least $70 \%$.

The absorption spectra in Figure S2 show that the nanotube concentration is relatively similar in the samples before and after the DNA replacement procedure.

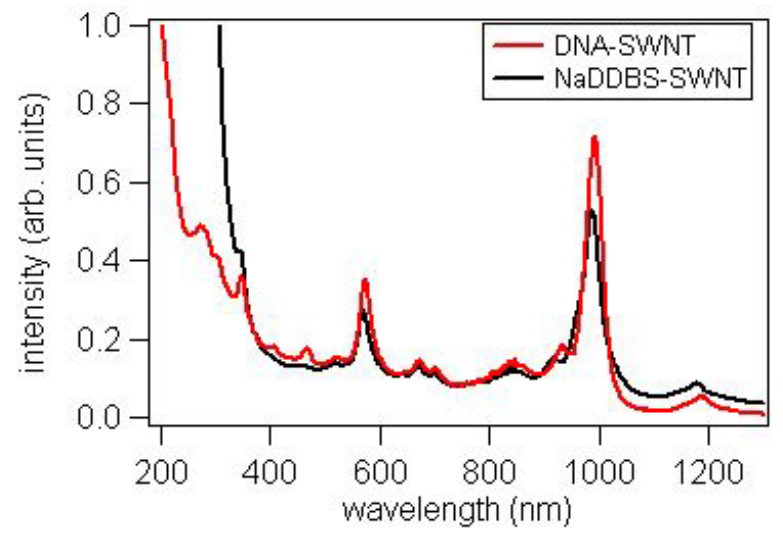

Figure S2. Absorption spectra of SWNTs before (DNA-SWNT) and after (NaDDBS-SWNT) the replacement of $\mathrm{d}(\mathrm{GT})_{20}$ with $\mathrm{NaDDBS}$.

\section{References:}

(1) Bachilo, S. M.; Balzano, L.; Herrera, J. E.; Pompeo, F.; Resasco, D. E.; Weisman, R. B. J Am Chem Soc 2003, 125, 11186-11187.

(2) Zheng, M.; Jagota, A.; Semke, E. D.; Diner, B. A.; Mclean, R. S.; Lustig, S. R.; Richardson, R. E.; Tassi, N. G. Nat Mater 2003, 2, 338-342.

(3) Zheng, M.; Jagota, A.; Strano, M. S.; Santos, A. P.; Barone, P.; Chou, S. G.; Diner, B. A.; Dresselhaus, M. S.; McLean, R. S.; Onoa, G. B.; Samsonidze, G. G.; Semke, E. D.; Usrey, M.; Walls, D. J. Science 2003, 302, 1545-1548.

(4) Zheng, M.; Diner, B. A. J Am Chem Soc 2004, 126, 15490-15494. 